\title{
CHANGES IN THE SKUTA GLACIER (SOUTHEASTERN ALPS) ASSESSED USING NON-METRIC IMAGES
}

Mihaela Triglav Čekada, Patricija Barbo, Miha Pavšek, Matija Zorn

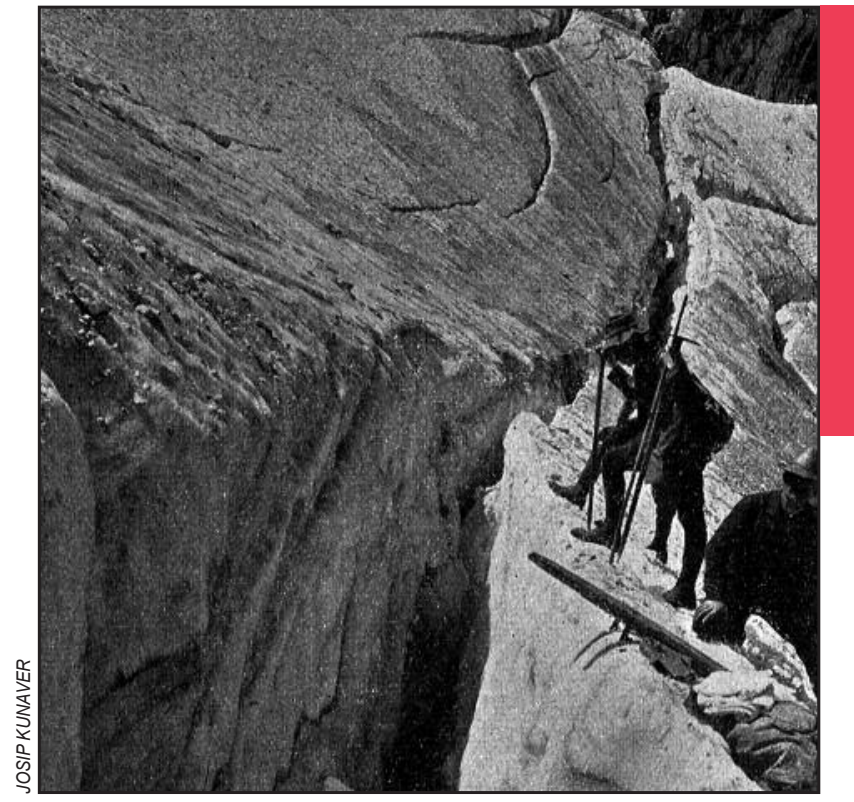

Crevasse on the Skuta Glacier in 1913 (Kunaver 1913). 
DOI: https://doi.org/10.3986/AGS.7674

UDC: 91:551.324(234.323Skuta)

528.7:551.324(234.323Skuta)

COBISS: 1.01

Mihaela Triglav Čekada' ${ }^{1}$ Patricija Barbo², Miha Pavšek³, Matija Zorn ${ }^{3}$

\section{Changes in the Skuta Glacier (southeastern Alps) assessed using non-metric images}

ABSTRACT: The Skuta Glacier in the Kamnik-Savinja Alps (in northern Slovenia) is one of the two remaining glaciers in Slovenia. It is located in a cirque oriented toward the northwest, which shields it from sunlight for most of the year. The glacier lies at an average elevation of $2070 \mathrm{~m}$. In recent years, its average area has measured around 1.5 hectares. Monitoring of the glacier has been performed since 1946. In 1962, regular photographing of the glacier with various cameras started from various non-fixed standpoints. Using the single image interactive orientation acquisition method, in which a single photograph is compared with the projection of a modern digital terrain model, seventeen photographs covering the period from 1970 to 2015 were used to acquire the $3 \mathrm{D}$-perimeters of the glacier. The data shows that the elevation of glacier's upper edge decreased by approximately $40 \mathrm{~m}$ in the last half-century. Changes in the glacier's area and average upper edge elevation were compared with average annual temperature and maximum seasonal snow cover depth.

KEY WORDS: very small glacier, glacieret, climate change, non-metric images, interactive orientation, Skuta Glacier, Slovenia

\section{Ugotavljanje sprememb na Ledeniku pod Skuto (jugovzhodne Alpe) na podlagi nemerskih fotografij}

POVZETEK: Ledenik pod Skuto v Kamniško-Savinjskih Alpah je poleg Triglavskega ledenika eden od dveh še ohranjenih preostankov ledenikov v Sloveniji. Leži v krnici z usmerjenostjo proti severozahodu, zato je večino leta v senci. Ledenik ima povprečno nadmorsko višino 2070 m, njegova površina pa je bila v zadnjih nekaj letih okrog poldrugega hektarja. Ledenik merijo od leta 1946, od leta 1962 pa so ga z različnimi fotoaparati tudi redno fotografirali iz različnih nestabiliziranih stojišč. S pomočjo interaktivne metode orientacije, pri kateri vsebino na fotografijah primerjamo s projekcijo sodobnega digitalnega modela reliefa, smo preučili 17 posnetkov in iz njih izmerili trirazsežnostne obode ledenika v obdobju 1970-2015. V zadnjega pol stoletja se je ledenik na zgornjem robu stanjšal za skoraj $40 \mathrm{~m}$. Spremembe površine in povprečne višine zgornjega robu ledenika smo primerjali s povprečno letno temperaturo in največjo sezonsko skupno višino snežne odeje.

KLJUČNE BESEDE: majhni ledeniki, podnebne spremembe, nemerske fotografije, interaktivna orientacija, Ledenik pod Skuto, Slovenija

The paper was submitted for publication on 6th November, 2019.

Uredništvo je prejelo prispevek 6. novembra 2019.

\footnotetext{
${ }^{1}$ Geodetic Institute of Slovenia and Faculty of Civil and Geodetic Engineering, University of Ljubljana, Ljubljana, Slovenia mihaela.triglav@gis.si (https://orcid.org/0000-0002-4200-2616)

${ }^{2}$ barbo.patricija@gmail.com

${ }^{3}$ Research Centre of the Slovenian Academy of Sciences and Arts, Anton Melik Geographical Institute, Ljubljana, Slovenia

miha.pavsek@zrc-sazu.si (https://orcid.org/0000-0002-6543-6548),

matija.zorn@zrc-sazu.si (https://orcid.org/0000-0002-5788-018X)
} 


\section{Introduction}

The Skuta Glacier (Pavšek 2004, 2007) in the Kamnik-Savinja Alps is one of the two remaining glaciers in Slovenia, the other being the Triglav Glacier (Gabrovec et al. 2013, 2014; Triglav Čekada and Zorn 2020). It lies in a shady cirque, around 3 hectares in size, surrounded by rock walls. In contrast to the Triglav Glacier and the nearby Canin glaciers in Italy (Triglav Čekada, Zorn, and Colucci 2014), the past size of which can be assessed from the mid-nineteenth century onward based on various historical images (Triglav Čekada 2018), no images going back that far are available for the Skuta Glacier.

Systematic measurements of the Skuta Glacier began in 1946 (Meze 1955; Pavšek 2007), and in 1962 the glacier also began to be photographed during regular measurements at the end of the melting season (Košir 1976). Various cameras were used and photographs were taken from two positions: the lower edge of the Ledine Cirque and along the hiking trail near the fork between the routes to the Savinja Pass and the Rinka peaks, provisionally named Ob macesnu 'At the Larch' (Košir 1976).

This article presents the measurements of the glacier's perimeter and its upper edge acquired from the photographs taken from the standpoint "At the Larch. « The results are compared against the average annual temperature and the maximum seasonal snow cover depth. These two indicators have proven significant in similar studies of the Triglav Glacier (Triglav Čekada and Gabrovec 2013).

Today's Skuta Glacier is considered a very small glacier, or glacieret (Kumar 2011). The results of this study can thus be compared to other glaciers of similar size, especially those that lie at lower elevations in middle latitudes and are therefore heavily exposed to short-term climate changes (e.g., Djurović 2012; Colucci and Žebre 2016; Gachev and Mitkov 2019; Gachev 2020).

\section{Data and methods}

\subsection{Field measurements}

The initial observations of the Skuta Glacier included permanent marking of fixed measurement points around the glacier. At the end of each annual melting season, the glacier's retreat from these points was measured with a tape measure and a compass. Because the glacier lies in a cirque, most fixed measurement points were set on its upper edge or the rock walls surrounding the cirque. Consequently, (sub)vertical retreats were most often measured on the upper edge (Meze 1955; Košir 1976, 1986; Pavšek 2007) rather than horizontal retreats, which were typically measured in similar studies of the glaciers nearby (Triglav Čekada et al. 2012; Gabrovec et al. 2013; Colucci and Guglielmin 2015).

The (sub)vertical and horizontal retreat are published in articles covering the first four decades of measurements (Gams and Kopač 1955; Meze 1955; Košir 1976, 1986). Later the retreats were so extensive that the old fixed measurement points were no longer used. New ones were marked, but the retreats from these points are not directly comparable with the old ones (Pavšek 2007).

In 1997 and 2003, the first tachymetric surveying of the glacier was conducted and, since 2007, field surveys with annual geodetic measurements have been performed (Pavšek 2012).

In 2006, a steam drill was used to measure the thickness of the glacier (ice and firn). The average thickness was $7 \mathrm{~m}$ and the maximum thickness was nearly $12 \mathrm{~m}$. Its volume was estimated at just under $80,000 \mathrm{~m}^{3}$ (Pavšek 2007).

\subsection{Photography}

Since 1962, the glacier has also been photographed during regular field measurements (Košir 1976). Various cameras and positions have been used. This analysis only includes photographs taken from »At the Larch « (Table 1, Figure 1).

Photographic material makes it possible to reconstruct the glacier's upper edge before 1997, when the Skuta Galcier was geodetically surveyed for the first time, and it helps to reconstruct the glacier from 1997 until the next geodetic survey conducted in 2003 as well. Even though annual geodetic surveys have been conducted since 2007, photographs taken after 2007 were also studied for comparison. 
Table 1: Dates and photographers of the images analyzed (Figure 1).

\begin{tabular}{ll}
\hline Date & Photographer \\
\hline 26 September 1970 & Dušan Košir \\
22 September 1973 & Dušan Košir \\
8 July 1982 & Dušan Košir \\
22 September 1995 & Miha Pavšek \\
10 September 1998 & Miha Pav̌ek \\
28 October 1999 & Miha Pavšek \\
3 July 2001 & Miha Pavšek \\
5 October 2004 & Miha Pav̌sek \\
19 October 2005 & Miha Pavšek \\
23 September 2006 & Miha Pavšek \\
15 October 2007 & Miha Pavšek \\
11 September 2008 & Miha Pavšek \\
7 September 2009 & Miha Pavšek \\
21 September 2010 & Miha Pavšek \\
30 September 2011 & Miha Pavšek \\
29 August 2014 & Miha Pavšek \\
20 ctober 2015 & Miha Pavšek \\
\hline
\end{tabular}

\subsection{Aerial laser scanning}

In 2012, special aerial laser scanning (lidar) was performed twice on the Skuta Glacier: first on May 15th, at the end of the accumulation season, and on September 18th, at the end of the melting season. The scanning was performed using a Riegl LM5600 with a $1550 \mathrm{~nm}$ wavelength. The average point density was 8 points $/ \mathrm{m}^{2}$ and the flight altitude was $200 \mathrm{~m}$ above the glacier. In this analysis, a digital terrain model (DTM) with a grid size $1 \mathrm{~m} \times 1 \mathrm{~m}$ was used, produced from the September laser scanning (Triglav Čekada et al. 2013).

On August 29th, 2014 the glacier was scanned again as part of the national aerial laser scanning of Slovenia (Triglav Čekada and Bric 2015). This scanning was performed using a Riegl LMS-Q780 with a 1064 $\mathrm{nm}$ wavelength at a flight altitude of $1000 \mathrm{~m}$. A point cloud with a density of 5 points $/ \mathrm{m}^{2}$ and a $1 \mathrm{~m} \times 1 \mathrm{~m}$ DTM were produced as well. Because of a mild summer and previous above-average accumulation season, there was still an abundance of snow on the glacier and therefore these data were not used in the analysis.

\subsection{Meteorological data}

According to Košir $(1976,1986)$, changes in the area covered by the Skuta Glacier depend on the mean summer air temperature, and he also established a connection with the maximum seasonal snow cover depth. Both indicators have also proved significant in the monitoring of the Triglav Glacier (Triglav Čekada and Gabrovec 2013).

Because no direct meteorological data are available for the Skuta Glacier, approximations of the average annual air temperature and maximum seasonal snow cover depth were calculated based on data from nearby meteorological stations.

Meteorological data were obtained from the Slovenian Environment Agency (ARSO) online archive (Arhiv ... 2018). The nearest Slovenian meteorological station with an extended series of measurements is the one on Mount Krvavec. Standing at an elevation of $1742 \mathrm{~m}$, it has been collecting data since 1973 (marked in Figure 2 as »Krvavec 2 «). It is just under $8 \mathrm{~km}$ as the crow flies from the Skuta Glacier. The previous meteorological station on Mount Krvavec stood at an elevation of $1478 \mathrm{~m}$ (marked in Figure 2 as »Krvavec 1 «). Unfortunately, these stations do not provide a complete series of average annual temperatures and monthly snow cover depths for all the years studied. Data from the Krvavec 1 station covering the period from 1963 to 1973 were used for the analysis.

Because the current station stands lower than the average elevation of the Skuta Glacier, as did the previous station, data from the Kredarica meteorological station at an elevation of $2514 \mathrm{~m}$ were used to calculate 
the average annual temperature. This station is approximately $55 \mathrm{~km}$ from the Skuta Glacier and has complete data series from 1955 onward.

The average annual temperature from Mounts Kredarica and Krvavec were adjusted (Figure 2) using the vertical average annual temperature gradient for Zgornje Jezersko $\left(-0.44^{\circ} \mathrm{C} / 100 \mathrm{~m}\right.$; Ogrin, Koželj, and Vysoudil 2016). Figure 2 shows a similar fluctuation in adjusted average annual temperatures for both stations.

To obtain a more complete series of measurements, the adjusted average temperatures from Mount Kredarica were used as a better approximation of temperature conditions at the average elevation of the Skuta Glacier. From 1960 to 1990 , the average annual temperature on Mount Kredarica was $-1.66^{\circ} \mathrm{C}$. According to Ogrin, Koželj, and Vysoudil (2016), the average annual temperature at Zgornje Jezersko during the same period was $5.9^{\circ} \mathrm{C}$. Based on the vertical temperature gradient between Mount Kredarica and Zgornje Jezersko, or between the elevations of $2514 \mathrm{~m}$ and $894 \mathrm{~m}$, the adjusted average annual temperature for Zgornje Jezersko is $5.46^{\circ} \mathrm{C}$.

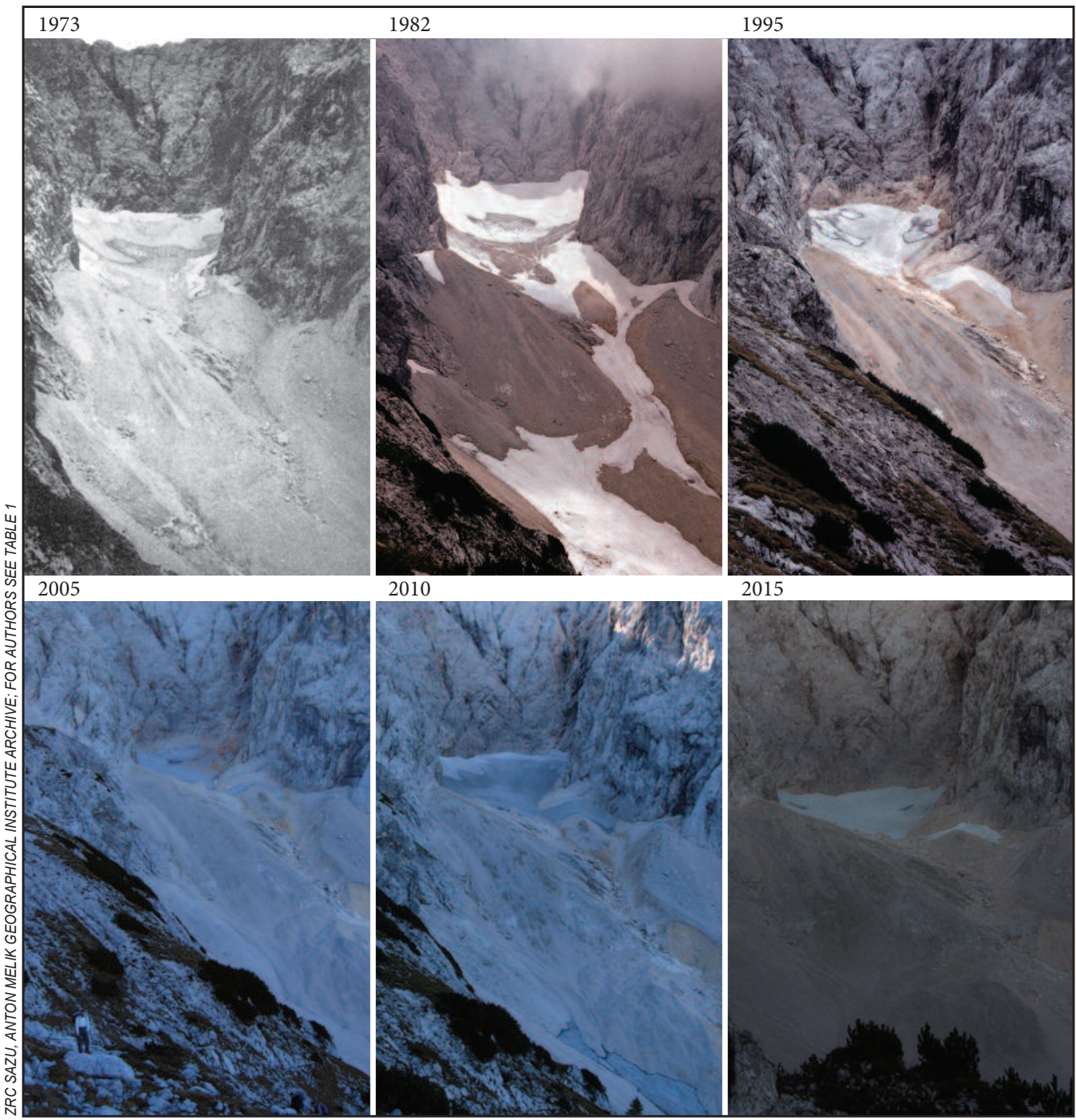

Figure 1: Some of the photographs of the Skuta Glacier from »At the Larch« used for the analysis, taken in 1973, 1982, 1995, 2005, 2010, and 2015. 


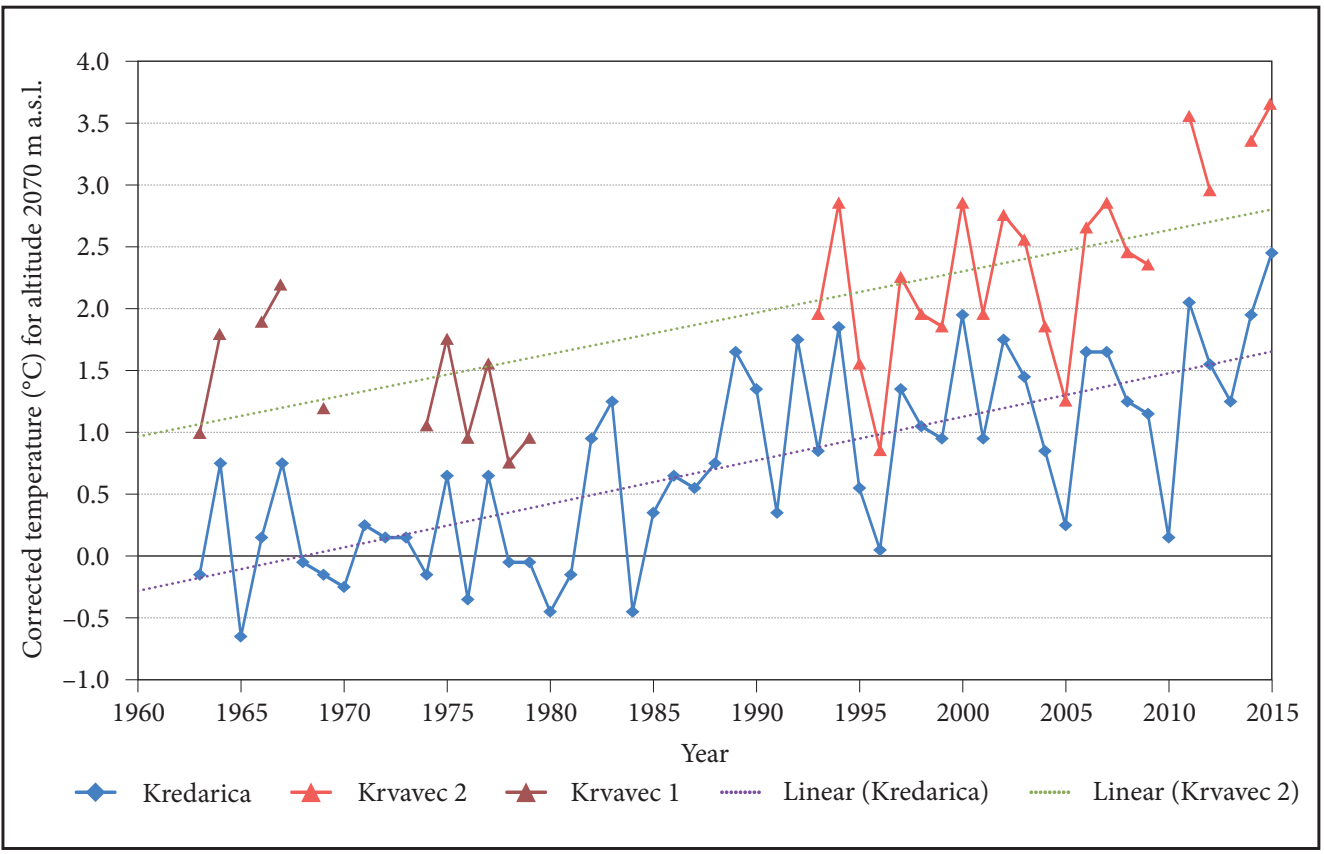

Figure 2: Average annual temperatures on Mounts Kredarica and Krvavec adjusted to the average elevation of the Skuta Glacier $(2070 \mathrm{~m})$.

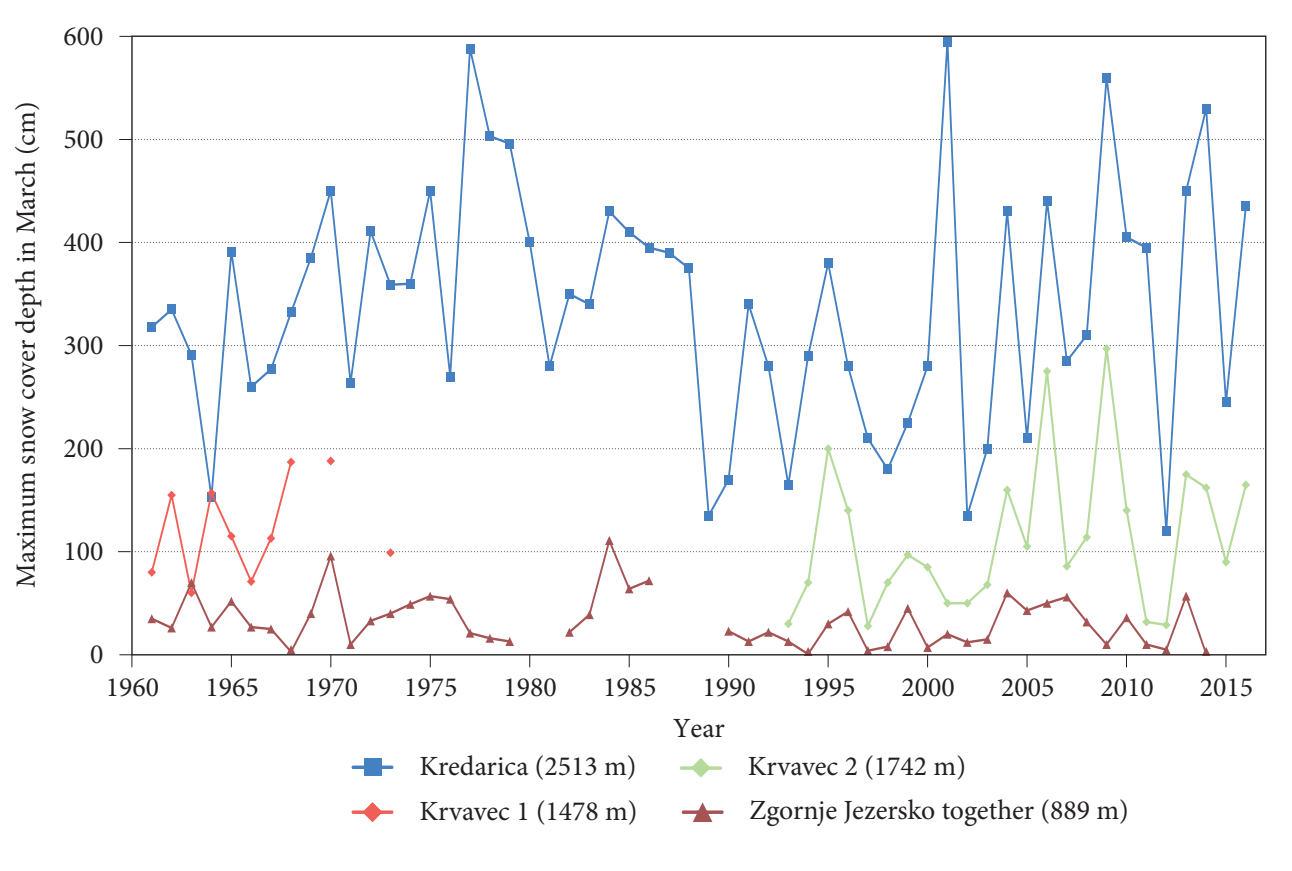

Figure 3: Maximum March snow cover depth on Mounts Kredarica and Krvavec, and at Zgornje Jezersko, based on aggregated data from the meteorological stations there. 
Data on snow cover depth were also obtained from the ARSO online archive (Figure 3); the data from seven meteorological stations at Zgornje Jezersko (at elevations ranging from 876 to $912 \mathrm{~m}$ ) were also used. The longest time series were recorded at the site at an elevation of $889 \mathrm{~m}$ (1977-1985, 2006-2014), therefore this elevation was used as the reference elevation for Zgornje Jezersko.

From 1969 to 1970, 1995 to 1996, in 1999, from 2004 to 2007, and in 2015, concurrent changes in the snow cover depth can be observed on Mounts Kredarica and Krvavec, and at Zgornje Jezersko in March (Figure 3). The 1993-2014 data series for the Krvavec 2 station and the aggregated data series for the Zgornje Jezersko stations are very similar; at the same time, maximums were also recorded on Mount Kredarica.

The precipitation and snow cover depth are reported to increase linearly with elevation (Asaoka and Kominami 2012; Grünewald, Bühler, and Lehning 2014). Based on the linear dependence between the elevation and the average snow cover depth (based on the data presented in Table 2; $y$ is the average snow cover depth and $x$ is the elevation), the average snow cover depth for the Skuta Glacier was calculated (Table 2). The maximum (March) snow cover depth calculated was $228 \mathrm{~cm}$, which is $109 \mathrm{~cm}$ less than the snow cover depth at Mount Kredarica.

Table 2: Average March snow cover depth from 1961 to 2016 at various meteorological stations and elevations (* ${ }^{*}$ calculated based on linear dependence).

\begin{tabular}{lcc}
\hline Station & Elevation $(\mathrm{m})$ & Average snow cover depth $(\mathrm{cm})$ \\
\hline Kredarica & 2,513 & 337 \\
Krvavec 1 & 1,478 & 123 \\
Krvavec 2 & 1,742 & 112 \\
Zgornje Jezersko & 889 & 33 \\
Skuta Glacier & 2,070 & $228^{*}$ \\
\hline
\end{tabular}

\subsection{Single image interactive orientation acquisition method}

The perimeter and upper edge of the Skuta Glacier were acquired from single photographs from various years using the single image interactive orientation acquisition method, also known as monoplotting. It requires only one photograph and a detailed DTM to calculate the orientation parameters. The method was developed for measuring the Triglav Glacier (Triglav Čekada et al. 2011; Triglav Čekada, Bric, and Zorn 2014). The content in the photographs is visually compared against a modern DTM projection to obtain the best fit, in which the parameters of the external image orientation (i.e., three coordinates of the camera's projection center, three rotation angles, and the scale of the projected model) are searched for. If an image or parts of it have significant radial distortions, then these can be searched for as well (Triglav Čekada, Bric, and Zorn 2014). The basic premise, that allows us to use this method, is that there was no significant change in the terrain around the glacier between the time when the photograph was taken and the time when a modern DTM was created. If the interactive orientation is successful, the features seen in the image fit to those seen on the DTM projection. This is followed by a $3 \mathrm{D}$ vectorization of the glacier's edge based on the projected DTM points.

In this analysis, the September 2012 DTM was applied (Figure 4). The result of the vectorization is a continuous line showing the $3 \mathrm{D}$ perimeter of the glacier.

The vectorization of the Skuta Glacier was difficult because part of it is always obscured from the perspective photographed (the extreme left and right parts of the glacier in Figures 4 and 5). A similar challenge was also encountered in acquiring the sizes of the Canin glaciers (Triglav Čekada, Zorn, and Colucci 2014). The obscured part was added as follows: the glacier's edge in the visible section of the cirque was vectorized from the photograph and then the vectorization of its perimeter was continued along the isohypse in the obscured section.

By comparing the areas in three interactively oriented images, in which all three orientation angles were »distorted « by $\pm 0.2^{\circ}$, the precision of the area calculations through standard deviation can be estimated at \pm 0.1 hectares (Barbo 2018), which corresponds to $7 \%$ of the Skuta Glacier's area per average area of 1.5 hectares. 
The average elevation of the glacier's upper edge was calculated using 30 to 160 points acquired by the method used based on photographs in which the upper edge was visible. Some of the results at approximately ten-year intervals are shown in Figure 5.

To determine the glacier's perimeter, the entire area covered in snow, firn, or ice was measured, and not only the ice. The glacier's upper edge was also determined based on the same principle.

\section{Results}

The area covered by the Skuta Glacier remained approximately the same between 1970 and 2015 (between one and two hectares; Table 3, Figure 6). If the calculations made in this study are compared with the field measurements, it can be established that the results differ by up to 0.4 hectares, which corresponds to just under a third of the glacier's area. The method used yielded relatively smaller areas than those established through field measurements; the only exceptions were the results for 2007 and 2015.

Using this method, the largest area was measured for 1982; the photograph from this year shows a heavily snowed-in glacier and its surroundings (Figure 1). The entire area of the glacier in the cirque and the snowed-in tongue outside it was measured, which in fact covers not only the glacier, but also the adjacent snowfield. It also needs to be taken into account that the photograph was taken more than two months before the end of the melting season (i.e., in early July; Table 1).

There are no major differences in the glacier's size between the start and end of the period studied, but significant changes can be observed in the elevation of its upper edge and thus its thickness. During the period studied, the upper edge elevation decreased by nearly $40 \mathrm{~m}$ (Table 3, Figure 5). The elevation of the glacier's upper edge fluctuates significantly from year to year because the glacier's thickness greatly depends on the snow conditions and when the measurements are conducted in an individual year in relation to the end of the melting season. A distinct decrease in the elevation of the upper edge can be observed from the early 1970s to the end of the 1990s.

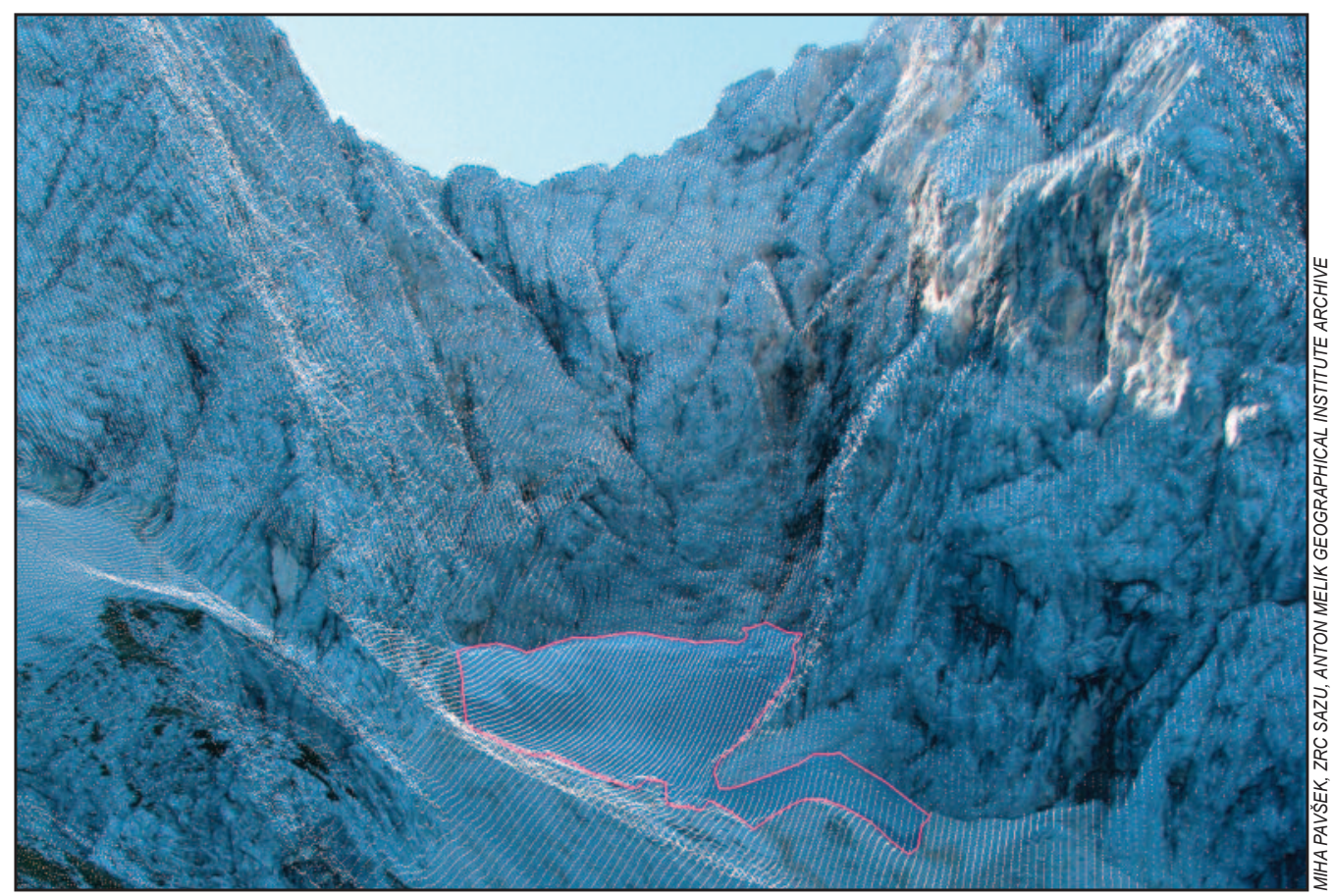

Figure 4: The Skuta Glacier in 2010 with a vectorized edge and a matching DTM projection. 


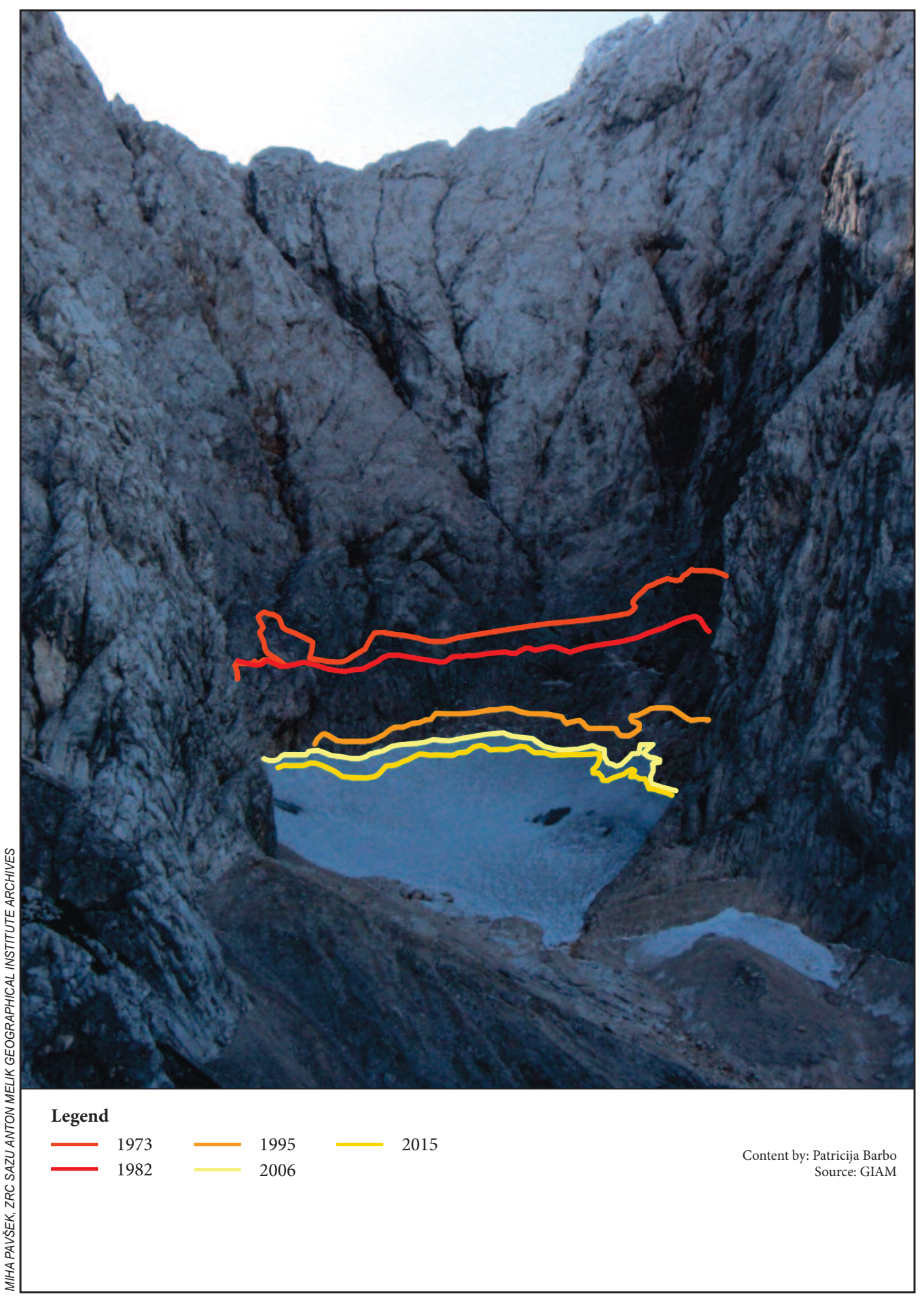

Figure 5: Elevation of the glacier's upper edge in 1973, 1982, 1995, 2006, and 2015 projected onto a 2015 photograph. 
Mihaela Triglav Čekada, Patricija Barbo, Miha Pavšek, Matija Zorn, Changes in the Skuta Glacier (southeastern Alps) assessed ...

\begin{tabular}{|c|c|c|c|}
\hline Year & $\begin{array}{l}\text { Area based on photographs } \\
\text { (hectares) }\end{array}$ & $\begin{array}{l}\text { Area based on field measurements } \\
\text { (hectares) }\end{array}$ & $\begin{array}{c}\text { Average elevation of upper edge } \\
\text { based on photographs }(\mathrm{m})\end{array}$ \\
\hline 1950 & - & 2.8 & - \\
\hline 1970 & 1.8 & & 2,153 \\
\hline 1973 & 2.3 & & 2,151 \\
\hline 1982 & $4.2^{* *}$ & - & 2,153 \\
\hline 1989 & & 1.1 & \\
\hline 1995 & 1.8 & - & 2,138 \\
\hline 1997 & & $1.5^{*}$ & \\
\hline 1998 & 1.4 & - & 2,114 \\
\hline 1999 & 1.1 & - & 2,109 \\
\hline 2001 & 1.0 & - & 2,129 \\
\hline 2004 & 1.6 & - & 2,114 \\
\hline 2005 & 1.0 & - & 2,100 \\
\hline 2006 & 1.3 & - & 2,111 \\
\hline 2007 & 1.5 & $1.1^{*}$ & 2,112 \\
\hline 2008 & 1.0 & $1.4^{*}$ & 2,119 \\
\hline 2009 & 1.4 & $1.8^{*}$ & 2,145 \\
\hline 2010 & 1.7 & $1.8^{*}$ & 2,124 \\
\hline 2014 & 2.1 & $2.1^{*}$ & 2,133 \\
\hline 2015 & 1.6 & $1.4^{*}$ & 2,115 \\
\hline
\end{tabular}

Changes in the glacier definitely reflect the increase in average annual temperatures (Figures 7 and 8 ). During the period studied, the average annual temperature at the glacier's average elevation increased from approximately $-0.2^{\circ} \mathrm{C}$ in 1963 to $1.7^{\circ} \mathrm{C}$ in 2015 . It is not only the increase of nearly $2^{\circ} \mathrm{C}$ that is important, but also the temperature transition above the freezing point.

In addition to temperature, changes in the glacier are also influenced by the snow cover depth. In addition to falling snow, the majority of snow accumulates on the Skuta Glacier in the form of avalanches and to a smaller extent as drifting snow.

A comparison of the Skuta Glacier's area and the average annual temperature after 2003 shows that from 2008 to 2010 the glacier's area increased when the average annual temperatures were below the temperature increase trend line. However, from 2004 to 2005, when the average annual temperatures were also lower than the trend, the area was shrinking (Figure 7). The difference between the two periods results from the differences in the maximum seasonal snow cover depths on the glacier in June (Figure 9).

An even more direct connection between the average annual temperature and the June snow cover depth is reflected by the changes in the average elevation of the glacier's upper edge (Figures 8 and 10). If the average temperatures are low, this makes it easier for the snow to remain on the upper edge until the end of the melting season. The impact of the snow cover depth on the elevation of the glacier's upper edge can be observed in 2009 and 2010. The year 2009 was characterized by a large amount of snow and a low average temperature and 2010 was marked by a low snow cover depth and a low average temperature. Consequently, the glacier's upper edge in 2009 was higher than in 2010. The upper edge also lowered in 1998 and 1999, when the average annual temperatures were slightly below the temperature trend line and there was very little snow in June.

\section{Discussion}

Because the Skuta Glacier is confined in a narrow cirque, it has managed to retain its area over the past half-century. However, this stability does not apply to its upper edge, where significant changes have been observed (Table 3, Figures 5 and 6). 
Acta geographica Slovenica, 60-2, 2020

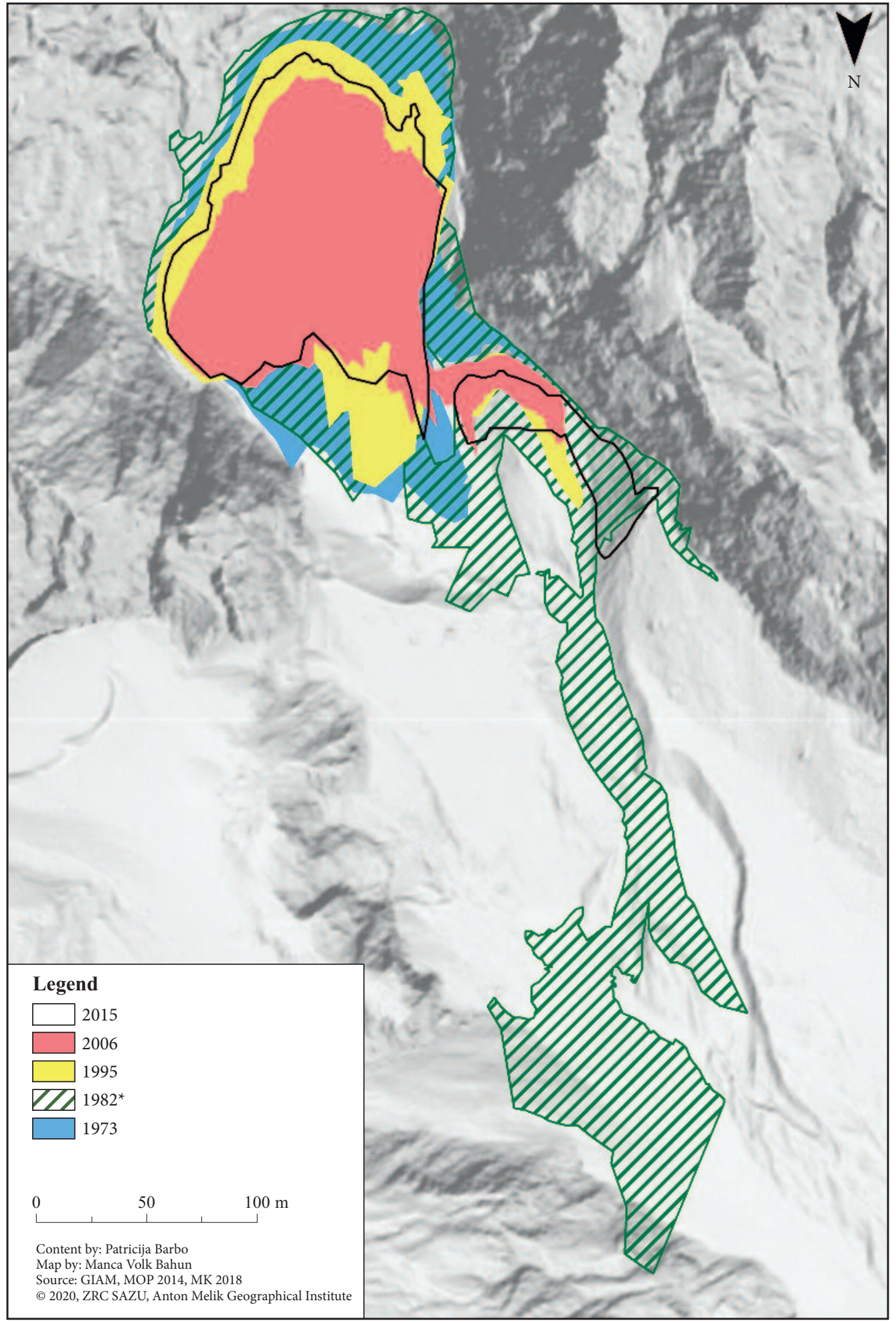




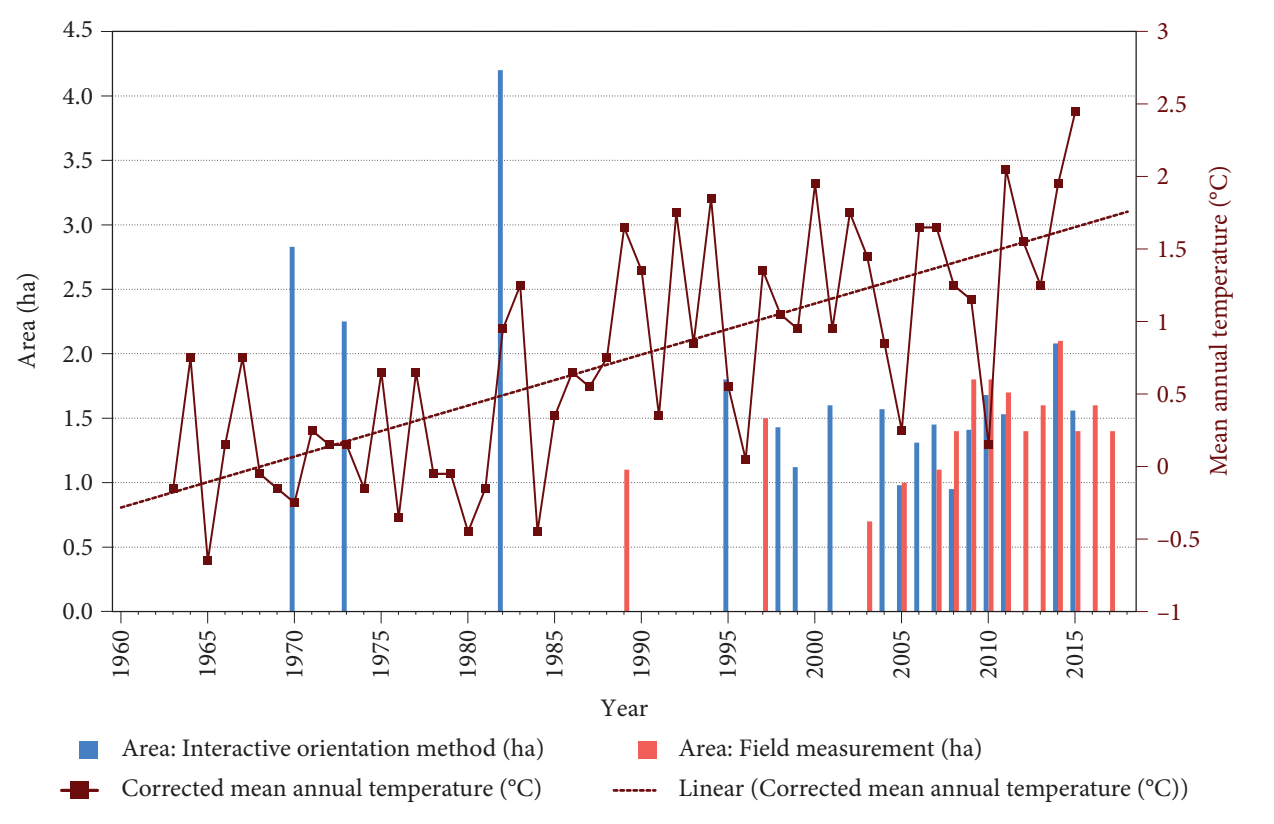

Figure 7: Areas covered by the Skuta Glacier measured using the single image interactive orientation acquisition method and field surveys and their comparison with average annual temperatures at an elevation of $2070 \mathrm{~m}$, or the average elevation of the Skuta Glacier.

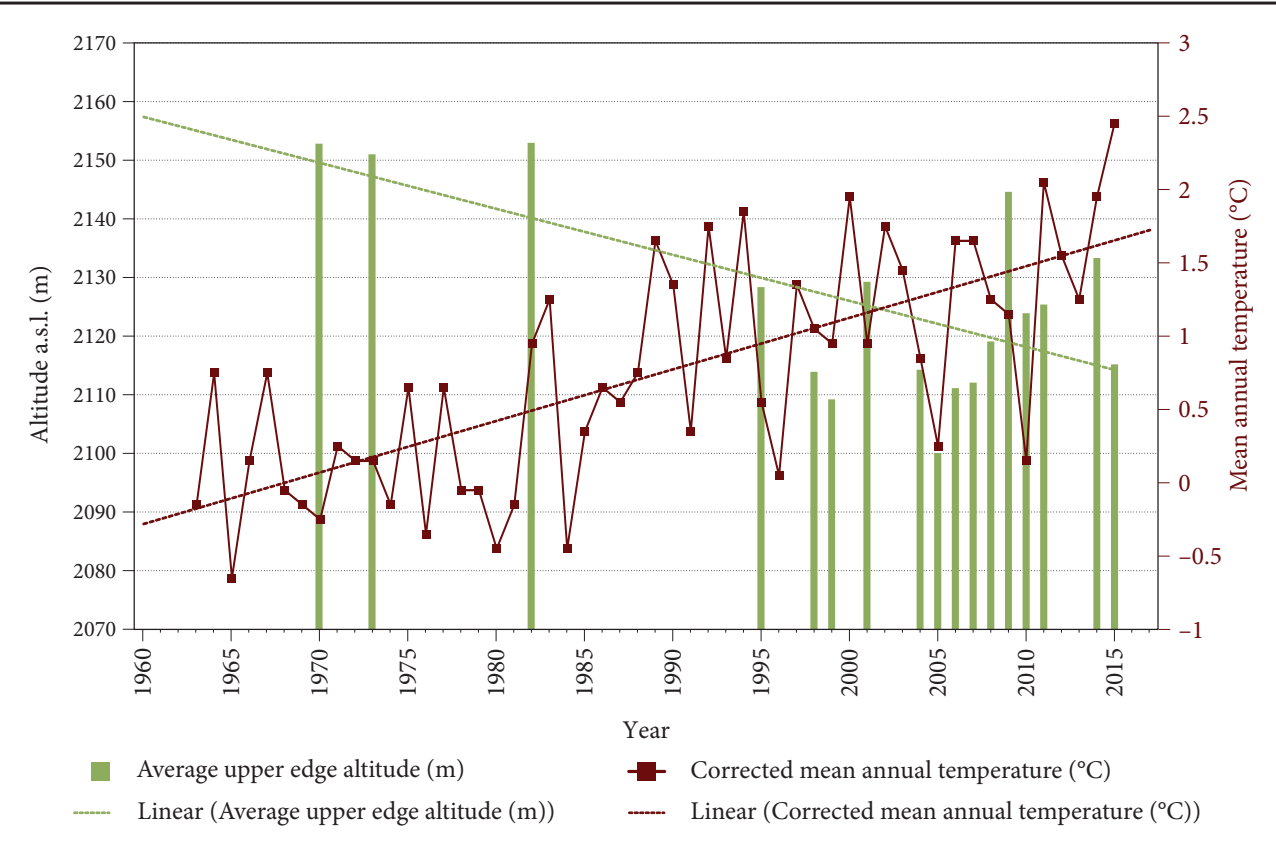

Figure 8: Annual elevations of the Skuta Glacier's upper edge determined with the single image interactive orientation acquisition method and their comparison with average annual temperatures at an elevation of $2070 \mathrm{~m}$, or the average elevation of the Skuta Glacier. 


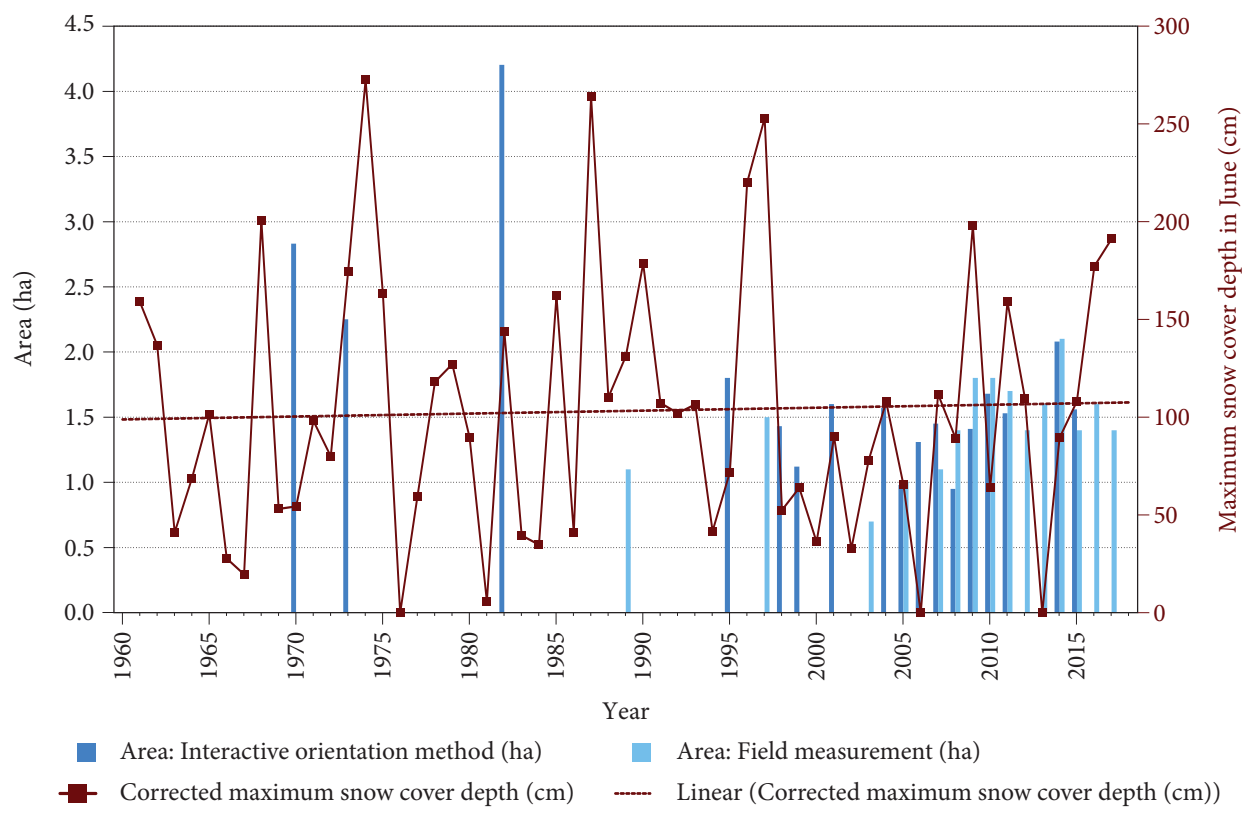

Figure 9: Areas covered by the Skuta Glacier measured using the single image interactive orientation acquisition method and field surveys, and their comparison with the maximum seasonal snow cover depth at an elevation of $2070 \mathrm{~m}$, or the average elevation of the Skuta Glacier, in June.

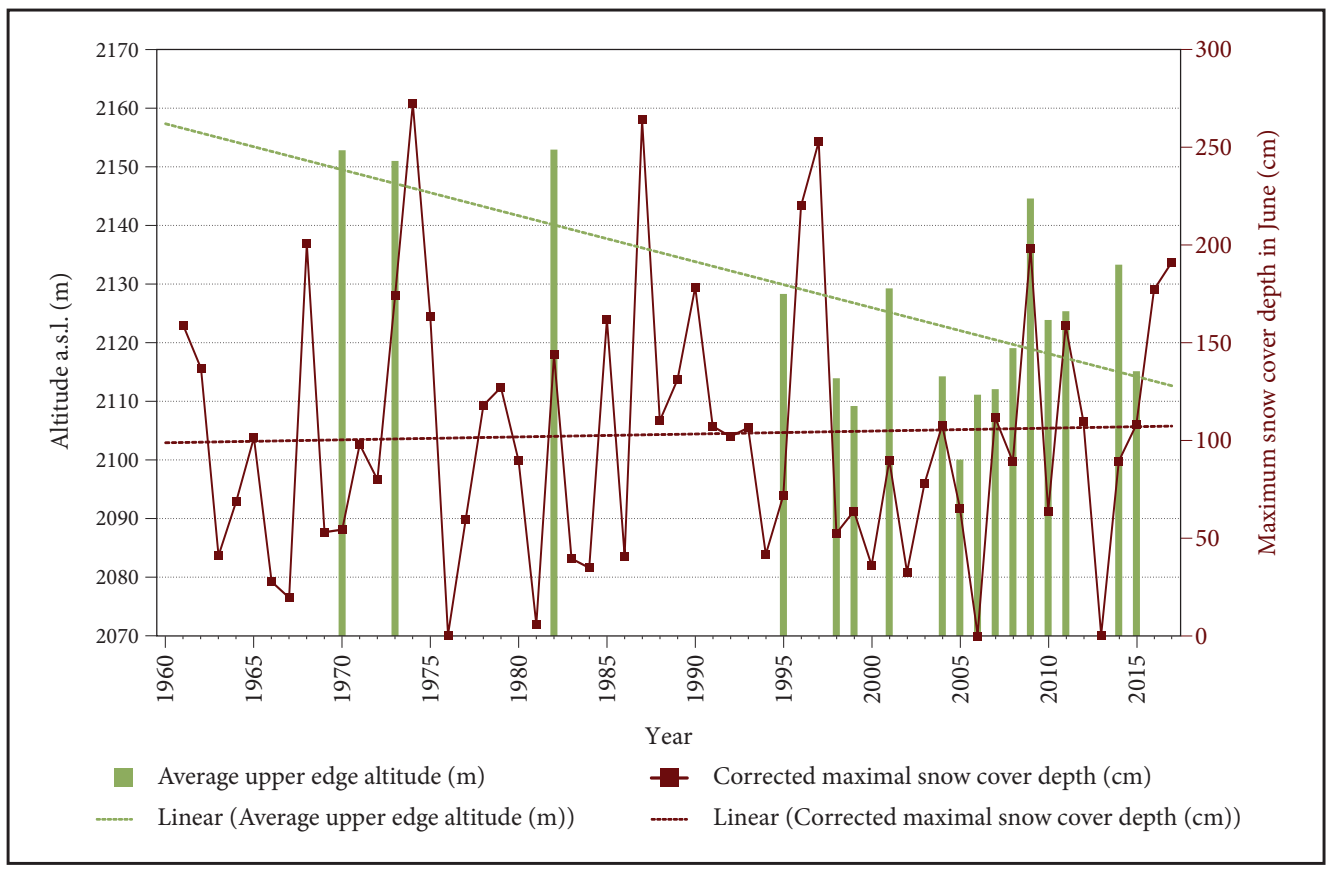

Figure 10: Annual elevations of the Skuta Glacier's upper edge determined with the single image interactive orientation acquisition method and their comparison with the maximum seasonal snow cover depth at an elevation of $2070 \mathrm{~m}$, or the average elevation of the Skuta Glacier, in June. 
The results of this study are based on the single image interactive orientation acquisition method (Triglav Čekada, Bric, and Zorn 2014), which has already been successfully applied to measurements of the Triglav Glacier (Triglav Čekada and Gabrovec 2013) and Canin glaciers (Triglav Čekada, Zorn, and Colucci 2014) in the Julian Alps. These measurements slightly deviate from the field surveys (Table 3 ) due to the poorer accuracy of the images compared to the field measurements, as well as problems in interpreting images due to poor contrast or difficulties distinguishing between snow or ice and calcareous debris. Mostly the single image interactive orientation acquisition method for the Skuta Glacier gives underestimated results compared to the area measured using tachymetric surveying. Nonetheless, the method used is useful for determining glacier changes because the size of glaciers can be measured based only on amateur photographs taken by non-metric cameras. First and foremost, the method is useful for very small glaciers, which can be documented in full in a single photo.

The data acquired for the Skuta Glacier can be compared to other very small glaciers in the southeastern Alps (Triglav Čekada et al. 2012; Colucci and Žebre 2016; Lipar et al. 2020; Triglav Čekada and Zorn 2020), southeastern Europe (Grunewald and Scheithauer 2010; Hughes 2010, 2018; Djurović 2012; Gachev, Stoyanov, and Gikov 2016; Gachev 2020), the Pyrenees (González Trueba et al. 2008), and elsewhere around the globe (DeBeer and Sharp 2009; Shahgedanova et al. 2012).

What all these studies have in common is that they connect the decrease in glaciers' size with the increase in the average annual temperature, the average temperature during the melting season, or average summer temperatures, which in reference to the Skuta Glacier has already been mentioned by Košir (1976, 1986). The likely connection between average temperatures and the snow cover depth on glaciers and snowfields in Slovenia was already discussed by Manohin and Gams (1959). In turn, contemporary authors, such as Grunewald and Scheithauer (2010), report that periods with above-average winter precipitation and cold summers can even »stabilize« very small glaciers or help them grow temporarily. This is also suggested by the data for the Skuta Glacier, which usually does not grow on the account of ice, but snow. On the other hand, Gachev and Mitkov (2019) associate the shrinking of very small glaciers with the increase in summer precipitation.

Over the past half-century, similar trends as elsewhere have been observed on very small glaciers in the southeastern Alps. The area covered by the Triglav Glacier halved from the mid-1980s to the early 1990s (it decreased from 10 to just over 4 hectares), and over the past two decades it has maintained an area between 0.5 and 1 hectares (Triglav Čekada and Gabrovec 2013). From the 1970s to the end of the century, the two Canin glaciers also halved in size, which was also assessed using the single image interactive orientation acquisition method (Triglav Čekada, Zorn, and Colucci 2014). In southeastern Europe, the size of the Debeli Namet Glacier in Montenegro, which lies at a similar elevation as the Skuta Glacier, has more than halved since the 1980s (Djurović 2012). In turn, the size of the Snežnik Glacier in Bulgaria, which lies at a similar elevation as the Triglav Glacier, more than halved from the early 1960s to the mid-1990s (Gachev, Stoyanov, and Gikov 2016). The current average annual temperature on the Debeli Namet Glacier is above $0{ }^{\circ} \mathrm{C}$ (Grunewald and Scheithauer 2010), just like on the Skuta Glacier. Over the past decade, both the Debeli Namet and Snežnik glaciers have more or less retained their size: the size of the former fluctuates between 1.5 and 3.0 hectares, and that of the latter between just under 0.4 and just over 0.6 hectares. Their relative stability is associated with the strong influence of terrain on the microclimate (Gachev, Stoyanov, and Gikov 2016; Gachev 2020). DeBeer and Sharp (2009) also establish that terrain influences how very small glaciers respond to climate change. Grunewald and Scheithauer (2010) add that in the concluding stages of glacial degradation the impact of climate factors relatively decreases, whereas the impact of terrain increases. According to the measurements conducted on both Slovenian glaciers (i.e., the Skuta Glacier and the Triglav Glacier; Triglav Čekada and Zorn 2020), these findings may apply to Slovenia’s very small glaciers.

\section{Conclusion}

Changes in the Skuta Glacier since the early 1970s were studied based on seventeen photographs taken from the same location using various non-metric cameras. The area covered by the glacier and the elevation of its upper edge were determined using the single image interactive orientation acquisition method.

During the period studied (1970-2015), the glacier's size did not change significantly, whereas the average elevation of the glacier's upper edge decreased by as much as nearly $40 \mathrm{~m}$. 
Because there is no meteorological station near the Skuta Glacier, data from nearby stations were used to determine the average annual temperature and maximum seasonal snow cover depth on the glacier. The maximum seasonal snow cover depth at the end of the accumulation season has proven vital for preserving the glacier's thickness.

ACKNOWLEDGMENTS: The authors acknowledge the financial support from the Slovenian Research Agency research project funding Predictive analytics based on location-associated context enrichment (J28176) and research core funding Geography of Slovenia (P6-0101). The authors would like to thank everyone involved in the measurements of the Skuta Glacier, without whom this study would not have been possible.

\section{References}

Arhiv - Opazovani in merjeni meteorološki podatki po Sloveniji. Agencija Republike Slovenije za okolje. Ljubljana. Internet: http://meteo.arso.gov.si/met/sl/archive/ (19. 12. 2018).

Asaoka, Y., Kominami, Y. 2012: Spatial snowfall distribution in mountainous areas estimated with snow model and satellite remote sensing. Hydrological Research Letters 6. DOI: https://oi.org/10.3178/hrl.6.1

Barbo, P. 2018: Uporaba interaktivne metode fotogrametrične orientacije posnetkov na primeru Ledenika pod Skuto. B.Sc. Thesis, Faculty of Civil and Geodetic Engineering, University of Ljubljana. Ljubljana.

Colucci, R. R., Guglielmin, M. 2015: Precipitation - temperature changes and evolution of a small glacier in the southeastern European Alps during the last 90 years. International Journal of Climatology 35-10. DOI: https://doi.org/10.1002/joc.4172

Colucci, R. R., Žebre, M. 2016: Late Holocene evolution of glaciers in the southeastern Alps. Journal of Maps 12-1. DOI: https://doi.org/10.1080/17445647.2016.1203216

DeBeer, C. M., Sharp, M. J. 2009: Topographic influences on recent changes of very small glaciers in the Monashee Mountains, British Columbia, Canada. Journal of Glaciology 55-192. DOI: https://doi.org/ $10.3189 / 002214309789470851$

Djurović, P. 2012: The Debeli Namet glacier (Durmitor, Montenegro) - from the second half of the $20^{\text {th }}$ century to the present. Acta geographica Slovenica 52-2. DOI: https://doi.org/10.3986/AGS52201

Gabrovec, M., Hrvatin, M., Komac, B., Ortar, J., Pavšek, M., Topole, M., Triglav Čekada, M., Zorn, M. 2014: Triglavski ledenik. Geografija Slovenije 30. Ljubljana. DOI: https://doi.org/10.3986/9789610503644

Gabrovec, M., Ortar, J., Pavšek, M., Zorn, M., Triglav Čekada, M. 2013: The Triglav glacier between the years 1999 and 2012. Acta geographica Slovenica 53-2. DOI: https://doi.org/10.3986/AGS53202

Gachev, E. 2020: Small glaciers in the Dinaric Mountains after eight years of observation: On the verge of extinction? Acta geographica Slovenica 60-2. DOI: https://doi.org/10.3986/AGS.8092

Gachev, E., Mitkov, I. 2019: Small glaciers in Pirin (Bulgaria) and Durmitor (Montenegro) as glaciokarstic features. Similarities and differences in their recent behaviour. Quaternary International 504. DOI: https://doi.org/10.1016/j.quaint.2018.03.032

Gachev, E., Stoyanov, K., Gikov, A. 2016: Small glaciers on the Balkan Penninsula: State and changes in the last several years. Quaternary International 415. DOI: https://doi.org/10.1016/j.quaint.2015.10.042

Gams, I., Kopač, V. 1955: Poročilo o opazovanju in merjenju ledenika na Skuti 16. septembra 1954. Geografski zbornik 3.

González Trueba, J. J., Martín Moreno, R., Martínez de Pisón, E., Serrano, E. 2008: 'Little Ice Age' glaciation and current glaciers in the Iberian Peninsula. The Holocene 18-4. DOI: https://doi.org/10.1177/ 0959683608089209

Grunewald, K., Scheithauer, J. 2010: Europe's southernmost glaciers: response and adaptation to climate change. Journal of Glaciology 56-195. DOI: https://doi.org/10.3189/002214310791190947

Grünewald, T., Bühler, Y., Lehning, M. 2014: Elevation dependency of mountain snow depth. The Cryosphere 8-6. DOI: https://doi.org/10.5194/tc-8-2381-2014

Hughes, P. D. 2010. Little Ice Age glaciers in Balkans: low altitude glaciation enabled by cooler temperatures and local topoclimatic controls. Earth Surface Processes and Landforms 35-2. DOI: https://doi.org/ $10.1002 /$ esp. 1916

Hughes, P. D. 2018: Little Ice Age glaciers and climate in the Mediterranean mountains: a new analysis. Cuadernos de Investigación Geográfica 44-1. DOI: https://doi.org/10.18172/cig.3362 
Košir, D. 1976: Ledenik pod Skuto od leta 1955 do leta 1973. Geografski zbornik 15.

Košir, D. 1986: Ledenik pod Skuto v letih 1974-1985. Geografski zbornik 26.

Kumar, R. 2011: Glacieret. Encyclopedia of snow, ice and glaciers. Dordrecht. DOI: https://doi.org/10.1007/ 978-90-481-2642-2_203

Kunaver, J. 1913: Nesreča na Skuti. Planinski vestnik 19-8.

Lipar, M., Pérez, A. M., Tičar, J., Pavšek, M., Gabrovec, M., Hrvatin, M., Komac, B., Zorn, M., Zupan Hajna, N., Zhao, J.-X., Ferk, M. 2021: Subglacial carbonate deposits as a potential proxy for glacier's former presence. The Cryosphere 15. DOI: https://doi.org/10.5194/tc-15-17-2021

Manohin, V., Gams, I. 1959: O nastanku in ohranitvi snežišč in ledenikov v gorah. Geografski vestnik 31.

Meze, D. 1955: Ledenik na Triglavu in Skuti. Geografski zbornik 3.

Ogrin, D., Koželj, T., Vysoudil, M. 2016: Lokalno podnebje in topoklimatska karta Jezerskega. Dela 45. DOI: https://doi.org/10.4312/dela.45.5-30

Pavšek, M. 2004: Ledenik pod Skuto: Ledeniški dragulj na senčni strani Kamniško-Savinjskih Alp. Geografski obzornik 51-3.

Pavšek, M. 2007: Ledenik pod Skuto kot pokazatelj podnebnih sprememb v slovenskem delu Alp. Dela 28. DOI: https://doi.org/10.4312/dela.28.207-219

Pavšek, M. 2012: Večinoma krotke ledene pošasti: ledeniki - zanimivi naravni pojavi gorskih pokrajin. Planinski vestnik 112-2.

Shahgedanova, M., Nosenko, G., Bushueva, I., Ivanov, M. 2012: Changes in area and geodetic mass balance of small glaciers, Polar Urals, Russia, 1950-2008. Journal of Glaciology 58-111. DOI: https://doi.org/ 10.3189/2012JoG11J233

Triglav Čekada, M. 2018: Ledeniki na kartah vojaške izmere avstro-ogrske monarhije. Raziskave s področja geodezije in geofizike 2017. Ljubljana.

Triglav Čekada, M., Bric, V. 2015: Končan je projekt laserskega skeniranja Slovenije. Geodetski vestnik 59-3.

Triglav Čekada, M., Bric, V., Klanjšček, M., Barborič, B., Pavšek, M. 2013: Zračno lasersko skeniranje zasneženega površja. Raziskave s področja geodezije in geofizike 2012. Ljubljana.

Triglav Čekada, M., Bric, V., Zorn, M. 2014: How to decide which oblique image has the highest mapping potential for monoplotting method: a case studies on river erosion and floods. ISPRS Annals 2-5. DOI: https://doi.org/10.5194/isprsannals-II-5-379-2014

Triglav Čekada, M., Gabrovec, M. 2013: Documentation of Triglav glacier, Slovenia, using non-metric panoramic images. Annals of Glaciology 54-62. DOI: https://doi.org/10.3189/2013AoG62A095

Triglav Čekada, M., Radovan, D., Gabrovec, M., Kosmatin Fras, M. 2011: Acquisition of the 3D boundary of the Triglav glacier from archived non-metric panoramic images. The Photogrammetric Record 26-133. DOI: https://doi.org/10.1111/j.1477-9730.2011.00622.x

Triglav Čekada, M., Zorn, M. 2020: Thickness and geodetic mass balance changes for the Triglav Glacier (southeastern Alps) from 1952 to 2016. Acta geographica Slovenica 60-2. DOI: https://doi.org/10.3986/ AGS.7673

Triglav Čekada, M., Zorn, M., Colucci, R. R. 2014: Changes in the area of the Canin (Italy) and Triglav glaciers (Slovenia) since 1893 based on archive images and aerial laser scanning. Geodetski vestnik 58-2. DOI: https://doi.org/10.15292/geodetski-vestnik.2014.02.274-313

Triglav Čekada, M., Zorn, M., Kaufmann, V., Lieb, G. K. 2012: Measurements of small alpine glaciers: examples from Slovenia and Austria. Geodetski vestnik 56-3. DOI: https://doi.org/10.15292/geodetski-vestnik.2012.03.443-461 